\title{
Fundamental Objectives and Directive Principles of State Policy of Nigeria
}

\author{
Fatai Omotosho, Lecturer \\ Department of General Studies, Federal Polytechnic Ede, Osun State
}

\begin{abstract}
It is incontrovertible that one of the significant innovation in our constitutions in recent times is the inclusion of fundamental objectives and directive principle of state policy of Nigeria. However, it is not an understatement to say that the provisions on fundamental objectives and directives principles of state policy of Nigeria as enshrined in the 1979, 1989 and 1999 constitutions of the federal republic of Nigeria (as amended) are controversial. The controversy trailing the provision is not unconnected to its non enforceability and judiciability in our law courts. People have argued that the enforceability and judiciability have made the provisions unachievable, incapable of furthering the aims of good governance and sustainable development. I beg to differ. This paper wants to argue that even though all values are enforceable in the courts of public opinion, not all values(rights) are enforceable in the law courts. Thus the non-justifiability does not make the ideals and values (rights) unachievable and unimportant.
\end{abstract}

DOI: $10.7176 / \mathrm{JPCR} / 40-04$

\section{INTRODUCTION}

One of the innovations of the 1999 constitution of the federal republic of Nigeria is the inclusion of chapter II on fundamental objective and Directive principles of state policy of Nigeria(Awolowo, 2017,23). This provision has generated a lot of controversy among scholars .

The provision was one of the striking innovations in the 1979 constitutions. Historically, the provision has never featured in the Nigeria constitutions. The controversy surrounding the inclusion of the provision in the constitution is not unconnected with S6(6)c of the constitution ousting the jurisdiction of the courts to enforce provisions of chapter II of the constitution(Awolowo, 2017,23). For this reason, Some have argued against its inclusion (Abiola, 1978, V.). It has also been argued that the provision should be made justiciable so that it can be a veritable tool and platform for achieving nationaltransformation and sustainable development in Nigeria (Awolowo, 2017,23). According to Awolowo $(2017,25)$ "the provision has made critics to argue since the courts cannot enforce the directive principles as it does not create any justiciable right in favour of any individual, it should be best be suitable for the preamble of the constitution or manifesto of political parties. They are considered a mere pious hopes and as pirations... Thus one may entertain fear of achieving this lofty aspirations..."

This paper argues that the provisions are values and ideals of the Nigierian state. So they do not need to be justiciable to be a tool for achieving national transformation and development. The provisions are moral, social ,political values, standards and ideals that we need to evaluate individual and government actions and performance .To do this, they do not need to be enforceable or justiciable. These values are what they are important and their importance should not be downplayed(Nwasu,2017,29)

\section{On the Concept of values and Ideals}

The theory of value or axiology is the philosophical study of goodness or value in the widest sense of the term. The term originally means the worth of something.Values include knowledge, virtue,rights, aesthetic, experience, friendship.(Famakinwa,2012, 8 ) Values are ideals or standards with which we evaluate actions, people, things or situations or actions. Peace, justice, knowledge, rights etc are all examples of values that many people endorse (Joe and Jonathan, 2018, 1) so we may talk of personal value which are endorsed by individuals; moral values that help to determine what is morally right or wrong; and social and political values which are used to evaluate social and political institutions etc, (Joe and Jonathan, 2018, 1). values refers to the importance, worth or usefulness of something. There is no doubt, rights are important values (Famakunwa,2012, 8). Their importance and worth cannot be underestimated.

However, there are moral and legal rights. Moral rights are not enforceable and justi ciable while legal rights are enforceable and justiciable.

\section{MORAL AND LEGAL RIGHTS}

Rights are values (Famakinwa,2012,8) They are considered to be very important and worthy. Rights may be moral rights or legal rights. Moral rights are conceived of as rights that individuals are born with and have regardless of whether or not they have legal rights to protect them. To have a moral right to something is to be 
morally entitled to a certain respectful treatment from others or have a moral status even if it is not yet recognized by law. As Joel Feinberg(1980,137) puts it, to have a moral right is to have a "valid claim" to certain treatment from others. By "valid claim" Feinberg means a claim that is morally justified even if not necessarily established by law. For example, under the right not to be killed, there are moral entitlements to having one's life protected and respected by others, not only to not having one's life taken away from her, but also protected when necessary.

Legal rights refer to all those rights found within existing legal codes that are protected by law and enforceable. A legal right is a right that enjoys the recognition and protection of the law (enforceable). A legal right cannot be said to exist prior to its passing into law and the limits of its validity are set by the jurisdiction of the body that passed the relevant legislation. An example of a legal right would be women's right to vote and be voted for in Nigeria, as enshrined in the 1999 Constitution of the Federal Republic of Nigeria. Unlike moral rights which are grounded in moral reasons, legal rights derive from the laws of the society, legislature, customary rights that exist by local convention. Legal rights are such that, in theory, if they are violated, violator scan be punished by the criminal system (Omotosho 2017, 6 - 8).

Legal rights are liberties or protections individuals have because some law says they do. According to Bentham,legal right and law are correlative terms, just as son and father. legal right is the child of the law unlike moral rights. The rights in the provition of chapter 2 of the 1999 constitution are moral,economic, social and political values needed to evaluate individual government performance and actions.

\section{THE CONTENTS OF THE PROVISION}

The fundamental objectives of Nigeria as contained in Section 14 is that the Nigerian federation is conceived as a state that is based on the principles of democracy and social justice. The implication of this is that the government of Nigeria shall be democratically elected. The country shall be ruled by elected leaders not by military juntas. The government shall not be taken over by revolution or mobocracy or coup. That is, coup, mobocracy and revolution which are antithetical to democracy are prohibited. It also means that rule of law shall be upheld. The state or government shall be fair to all, individuals, groups, communities etc.

To achieve this objective, the state policy, the path or method to achieve this fundamental objective is stated in subsection (2c). "The participation by the people in their government shall be ensured in accordance with the provisions of this constitution". It means therefore that it is obligatory on the state, the federal republic of Nigeria, to create opportunities for the people to participate in government. The consequence of which is that government shall be responsible, responsive, and accountable to the people.

In pursuance of this basic objective of mass participation in government, the constitution in Section 3 provides that the composition of the federal government, it's agencies and the conduct of their affairs will be carried out in such a manner as to recognize the federal character of Nigeria in order to provide and promote national unity and command loyalty. This shall be done to ensure and avoid the predominance in the government or its agencies of persons from a few states or from a few ethnic groups or other sectional groups.

Consequently, sovereignty belongs to the people of Nigeria from whom government through the constitution derives all its powers and authority. The government, who derives all its power and legitimacy from the people through voting in election shall according to Section 14 (2)b shall have the primary purpose of ensuring the welfare of the people. The security of the people shall also be the primary duty of government at federal, state and local governments. In the words of the constitution(S.14) ,"the security and welfare of the people shall be the primary purpose of government". This therefore means that the role of Government or state is no longer limited to the maintenance of law and order and protection of life, liberty and property of the subjects. Consequently, there are constitutional declarations regarding political, economic, educational, environmental objectives etc as found in Chapter 2 of the 1999 constitution which deals with fundamental objectives and directive principles of state policy.

\section{Political Objectives}

The political objective of Nigeria is summarised by the framers of the constitution as unity and faith, peace and progress otherwise known as the motto of Nigeria. To achieve this fundamental objective, the need for national integration and active encouragement is emphasised. Discrimination on the grounds of place of origin, religion, sex, status, ethnic or linguistics association or ties is prohibited. For the purpose of promoting national integration, the constitution makes it obligatory for the state, the federal republic of Nigeria to provide adequate facilities and encourage free mobility of people, goods and services throughout the country, secure full residency rights for every citizen in all parts of the federation. It is also obligatory for the purpose of national integration for the state of Nigeria, to encourage inter-marriage among persons of different religions, ethnic groups, linguistics associations, or ties and among persons of different places and states of origin. The state is also expected to foster a feeling of belonging and of involvement among the various people of Nigeria so that loyalty to the country shall override sectional interests. The constitution also states that it is obligatory for the stste to 
abolish all corrupt practices and abuse of power.

\section{Economic objectives}

According to section 16 of the 1999 constitution, it is the obligation of the state to control the national economy for the minimum welfare, freedom and happiness of every Nigerian citizen on the basis of social justice, equality of status and opportunity.

The constitution provides for a mixed economy. It reserves the control, management and operations of the major sectors of the economy to the state. It also provides for a plan and balanced economic development in which the rights of the individual citizens are guaranteed to engage in any economic activity. The constitution frowns at concentration of wealth or the means of production and exchange in the hands of few individuals or groups. According to section 16 (1) c ,every citizen "Without prejudice to its right to operate or participate in areas of the economy, other than the major sectors of the economy, manage and operate the major sectors of the economy" while section 16 (2) c states that the economic system is not operated in such a manner as to permit the concentration of wealth or the means of production and exchange in the hands of the few individuals or of a group; and

A body is to be set up by the national assembly to review from time to time "the ownership and control of business enterprises operating in Nigeria and make recommendations to the president on same". This same body is to be empowered "to administer any law for the regulation of the ownership and control of such enterprise.

\section{Social objectives}

The social objective of Nigeria is to have a state where all citizens are free, equal and fairly treated. A state where the citizens enjoy freedom, are equal before the law and can access justice. Thus, the social order is founded on the ideals of freedom, equality and Justice. In pursuance of these fundamental social objectives of the state is to ensure equality of rights, obligations and opportunities before the law. That the santity of the human person is recognized; human dignity is maintained and enhance; that government actions are humane. That human exploitation in any form is prevented; that the independence of the judiciary, the impartiality of courts of law and easy accessibility to courts is secured and maintained.

In addition, the constitution directs and 'compels' the state to direct its policy towards ensuring that:

a) All citizens, without discrimination on any group whatsoever, have the opportunity for securing adequate means of livelihood as well as adequate opportunity to secure suitable employment;

b) conditions of work are just and humane, and that there are adequate facilities for leisure and for social, religious and cultural life;

C) the health, safety of welfare of all persons in employment are safeguarded and not endangered or abused.

d) there are adequate medical and health facilities for all persons;

e) there is equal pay for equal work without discrimination on account of sex or any other ground whatsoever;

f) Children, young persons and the aged are protected against any exploitation whatsoever and against moral and material neglect;

g) provision is made for public assistance in deserving cases or other actions of need; and

h) the evolution and promotion of family life is encouraged.

\section{Educational objectives}

The educational objective of the Nigerian state is to ensure that there are equal and adequate educational opportunities available at all levels to all Nigerians. The government is obliged or required to take possible steps to ensure that the educational opportunities available at all levels to people in any part of the federation are equal and available to those available in other parts or areas of the federation. So also government is to promote science and technology and strive to eradicate illiteracy. Towards this end, government is required to, as and when practicable, provide

a) free, compulsory and universal primary education.

b) free secondary education.

c) free University education; and

d) Free adult literacy programme.

\section{Foreign policy objectives of Nigeria}

The foreign policy objectives of Nigeria are; to promote and protect the national interest of Nigeria, to promote Africa integration and African unity; to promote international cooperation for the consolidation of universal peace and mutual respect among all nations and eradication of discrimination in all it's manifestation, to promote a just world economic order. Towards this end, Nigeria shall have respect for international law and treaty, obligations and seek resolution and settlement of international disputes by negotiation, arbitration and adjudication. The federal government is required to promote African unity and integration. By implication, 
Nigeria is to promote the total political economic, social and cultural liberation and freedom of Africa and other forms of international maintenance and consolidation of global peace and mutual respect and friendship among states, peoples and countries.

The constitution also requires the Government to combat racial discrimination in all it's ramifications.

\section{Environmental objectives}

It is the duty and obligations of the government to improve the environment and safeguard the water, air, forest and wildlife of Nigeria.

\section{Cultural objectives}

The state is required to protect, preserve and promote the Nigerian culture which enhances human dignity and is consistent with the fundamental objectives of Nigeria. The state shall also encourage development of technological and scientific studies which enhance cultural values.

\section{The obligation of the Mass Media}

Section 22 of the constitution is very important for formalising what was hitherto in the realm of convention. This section states that "The press, Radio, Television and other agencies of the mass media shall at all times be free to uphold the fundamental objectives contained in this chapter and uphold the responsibility and accountability of the Government to the people. Although the press and other agencies have traditionally performed the instructions stated above.However, one welcomes the innovation in the 1979 constitution in that for the first time those functions were being constitutionally recognized, acknowledged and defined in a positive manner while the 1989 and 1999 constitutions follow suite by reinstating and emphasising it in a pragmatic manner.

\section{The Ethical Objectives}

The Ethical objective of Nigeria is to produce good and virtuous citizens who are self-reliant and ready to work and live peacefully together for the progress of Nigeria. Consequently, the constitution states that "The national ethics of Nigeria shall be discipline, integrity, dignity of labour, social justice, tolerance, self reliance and patriotism".

\section{Duties of Nigerian Citizens}

The constitution states expressly in section 24 the duties of Nigerian citizens which include, abiding by the constitution, respecting its ideals, institutions, the National flag, the National anthem, the national pledge and legitimate authorities. This provision is aimed at inculcating the culture of patriotism in the country as well as a sense of obligation to the country. It also aims at preparing citizens for the leadership roles ahead.

The section (sction 24) also requires Nigerian citizens to help to "enhance the power, prestige and good name of Nigeria and render such national service as may be required".

Consequently, the Nigerian citizens are expected to render military service if required by the nation. The youths must be ready to assist the country in whatever capacity during war, disaster, calamity, whenever the country requires it. Citizens should perform their work or duty as best as they can. Citizens should support National policies actively and work hard to promote the good name of Nigeria and National development. Nigerian citizens who are educated are compel to serve the nation after their higher school education as members of national youth service corps (NYSC). They are expected to serve in this capacity for one year and required to serve in any part of the federation and in any capacity.

A citizen is required to make " make positive and useful contribution to the advancement, progress and well-being of the community where he resides"', respect the right of others, the progress of his community, cooperate with others in the community and support law and order, and participate in public or civil organization.

Citizens are expected to declare and pay their taxes honestly and promptly. Section 24(f) requires citizens to "declare his income honestly to appropriate and lawful agencies and pay his tax promptly".

Citizens are required to" render assistance to appropriate and lawful agencies in the maintenance of law and or order" That is to report or give information to law enforcement agents such as police, the military etc. Citizens are expected to help law enforcement agents by giving them necessary assistance that can help them to prevent crimes, detect crimes and so on. Citizens should be ready to expose corrupt officials and expose bribery and corruption.

\section{NON-JUDICIABILITY OF THE FUNDAMENTAL OBJECTIVES AND DIRECTIVE PRINCIPLES OF STATE POLICY.}

The provision on fundamental objectives and directive principles of state policy appear and seem to be 
mandatory especially as stated in S.13 which states "It shall be the duty of every citizen to abide by this constitution'. A cursory look and reading of the clauses in chapter two of the constitution conveys the impression that the provision is compulsory and must be obeyed. However, section 6(6)(c) states in clear terms that "the judicial powers vested in accordance with the foregoing provisions of this section shall not except as otherwise provided by this constitution extend to any issue or question as to whether any act or omission by any authority or person or as to whether or any law or judicial decision is in the conformity with the fundamentals objectives and directive principles of state policy set out in chapter 2 of this constitution". Section 6(6)(c) therefore appears to exclude the jurisdiction of the courts on questions relating to contravention of the provisions relating to chapter 2 on fundamental objectives and directive principles of state policy. As a matter of fact, the provisions in the chapter are not justiciable or enforceable through the law courts. They are Nigeria's objectives and ideals that the coutnry wants to achieve. The constitution Drafting Committee supports this assertion while rationalizing the inclusion of the ideals and values, "governments in developing countries have tended to be preoccupied with power and its material perquisites with scant regard for political ideals as to how society can be organized and ruled to the best advantage of all".

S.23 ,for instance contains Nigeria's moral rules and standards of conduct. They are moral values and standards of judgement. We dont need to go to court to enforce them. The so called rights in chapter 2 are moral rights and values which we do not need to be enforced in law courts. So it is a category mistake to categorise them as (legal) rights that must be justiciable.

The non justiciabily of the directives principles not withstanding, they are fundamental and so very important (Nwauzi,2017,30) These values,ideals and objectives can serve as yardstick for measuring the performance of governments - local,state and federal - in a multiparty system like Nigeria.

It may also assist the courts where there is an ambiguity in any provision of the constitution to read the minds of the legislature. The legislature it is presumed, do not make laws that are inconsistent with the fundamental objectives of Nigeria.

Though the provision in chapter 2 are not justiciable yet the provision remains the pillar of guide, direction and focus of attention for government at federal, state and local government.

According to Olu Awolowo, "the provisions constitute a bold attempt at bringing the second generation rights that is social, economic and environmental rights into the constitution. Since attemption has mainly been focused on civil and political rights in the human rights chapter of the constitution (chapter 4).

There is no doubt that the values in the fundamental objectives and directive principles of Nigeria have influenced government actions and are expected to be taken into account by any government wanting to build a state based on the principle of social justice.

\section{FUNDAMANTAL OBJECTIVES AND DIRECTIVE PRINCIPLES OF STATE POLICY}

Fundamental objectives and directive principles are the 'philophies', basic ideals and values that are entrenched in the constitution. These values and directives that government at the central, state and local government levels are expected to respect, obey and follow are what they are expected to be, ideals and values and so they are not justiciable. Though government(s) can be assessed and challenged morally if they fail to observe them but they can cannot be sued for not observing or doing them. For instance, it is stated in the fundamental objectives and directive principles of state policy that "Government shall direct it's policy towards ensuring that there are equal and adequate educational opportunities at all levels". And that "Government shall promote science and technology ", and "Government shall strive to eradicate illiteracy ; and to this end Government shall as and when practicable provide:

a) Free, compulsory and universal primary education.

b) Free, secondary education.

c) Free university education.

d) Free adult literacy programme"

Stated above is the educational objective of Nigeria. This educational objective has been a feature of our constitutions including the 1999 constitution yet most governments including the central or federal government are yet to offer free education at all levels even though the constitution directs them to do so. Why? This is because it is an ideal, aim or objective which is to be achieved and at when practicable. Its implementation is a function of available resources, government, willingness, etc unlike other inclusions in the constitution, fundamental objective and principles in chapter two of the 1999 constitution are moral values, ideals, moral principles or rules which the citizens cannot challenge the government for not doing . Government is morally expected to observe them in the interest of the citizens when practicable. One should note the clause "Government shall as at when practicable provide" - so, the instruction do not carry the force of law and consequently not justiciable.

However, governments are expected to observe fundamental objectives. These objectives include educational, environmental, cultural, mass media, national ethics etc. 
In the words of the constitution drafting committee that drafted the 1979 federal constitution of the Federal republic of Nigeria, fundamental objectives refers to the "ultimate objectives of the nation whilst directive principles of the state policy indicate the path which leads to those objectives". The 1979 ,1989,1999 constitutions of Nigeria therefore attempted to set the objectives and ideals required of any government sn Nigeria and lay down the standards which any Government in Nigeria must not go below.

This provision also featured in the current constitution, the 1999 constitution of the federal republic of Nigeria. Consequently, the 1999 constitution in section 13 stipulates that "it shall be the duty and responsibility of all organs of government and all authorities and persons, exercising legislative, executive or judicial powers, to conform to, observe and apply the provision of this chapter of the constitution". "This chapter " above refers to the chapter 2 on fundamental objectives and directive principles of state policy.

The fundamental objectives and directive principles stress the moral, political social economic etc values, ideals, aims and ethics of Nigeria. Consequently, constitutional declaration regarding political, social, economic, educational foreign policy, environmental, cultural objectives and national ethics of Nigeria are provided in chapter two of the 1999 constitution of the federal republic of Nigeria. Section 14 of the 1999 constitution states the foundation upon which the Nigerian state is built. The country shall be ruled by the principles of democracy that is, government shall be democratic, where the people shall be free to elect their leaders under a free and fair election. In other words, Nigerians shall not be ruled by force or any undemocratic government. Section 15 states the political objectives of the state, Section 16 declares the economic objectives of the state while Section 17 codifies the social objectives of the state. Section 18 states the educational objectives of Nigeria. Sections 19 and 20 explains the foreign policy and environmental objectives of Nigeria respectively. While Section 21 states the directives on Nigerian culture, Sections 22 and 23 incorporate the obligations of the mass media as well as the directive on National Ethics. Section 24 contains or highlights the duties of the citizens which includes obeying the laws of the land and abiding by the constitution, respects ideals and institutions, the national anthem, national pledge, the national flag and constituted authorities. Pay tax as at when due and properly..

\section{Conclusion}

This paper has examined the inclusion of chapter 2 on fundamental objectives and directive principles of State policy. It has been shown that the rights and objectives stated in this provision are values, aims, ideals of Nigeria. The rights(values) are moral rights which are not justiciable. To campaign for their justiciability is to misrepresent or misunderstand what they are. They are values, what the people consider important, and fundamental.They are fundamental objectives. They are fundamental aims and ideals that we want to achieve and preserve. The importance of these values were also highlighted to support the claim that they are values that we consider important. So, individuals and Government's performance should be measured and evaluated on the basis of these moral, social, political and economic values.

\section{REFERENCES}

Abiola Ojo, (1978) Report of Constitutional Drafting Committee VOL.I. pg. V

Omotosho I.F.(2017) "A philosophical Defence of Aminal Rights" A thesis submited to the Obafemi Awolowo University in partial fulfillment of the requirement for the award of the degree of Doctor of philosophy in philosophy.

Joe L,\& Jonathan C (2018) "Three types of values",

https://philosophy.hku.hk/think/value/values.php

Nwabueze B. O. (1998)“The value of Human Rights and their challenge for Africa” paper delivered at the Annual conference of the Nigeria Bar Association at Abuja on 27thAugust, p 16

Nwazuzi L. (2017) "How Fundamental are the Fundamental Objectives and Directive Principles Under Chapter II of the Constitution of Nigeria 1999”. Donnish Journal of Law and Conflict Resolution, Vol 3(3) November, 2017, 29-34.

Olu Awolowo (2017) "Fundamental Objectives and Directive Principles of State Policy as Panacea for National Transformation and Sustainable Development in Nigeria". Journal of Law, Policy and Globalization, Vol.65, 2017, 23-27.

1999 Constitution of the Federal Republic of Nigeria 